\title{
Animal Welfare Policies and Human Rights in the Context of Slaughter Procedures
}

\author{
Giancarlo Bozzo ${ }^{1, *(\mathbb{D})}$, Roberta Barrasso ${ }^{1} \mathbb{D}$, Davide Ferorelli ${ }^{2}$, Vito Gassi ${ }^{3}$, Roberto Russo ${ }^{4}$ \\ and Francesco Emanuele Celentano 5
}

1 Department of Veterinary Medicine, University of Bari Aldo Moro, Strada Provinciale per Casamassima, km 3, 70010 Valenzano, Italy; roberta.barrasso@uniba.it

2 Interdisciplinary Department of Medicine, University of Bari Aldo Moro, Piazza Umberto I, 70121 Bari, Italy; davide.ferorelli@uniba.it

3 Department of Public, International and Community Law, University of Padova, Via 8 Febbraio 1848, 2, 35122 Padova, Italy; vito.gassi@phd.unipd.it

4 Student in International Business Management, London Metropolitan University, 166-220 Holloway Rd, London N 78 DB, UK; ror0319@my.londonmet.ac.uk

5 Department of Law, University of Bari Aldo Moro, Piazza Umberto I, 70121 Bari, Italy; francesco.celentano@uniba.it

* Correspondence: giancarlo.bozzo@uniba.it; Tel.: +39-080-5443-851

check for updates

Citation: Bozzo, G.; Barrasso, R.; Ferorelli, D.; Gassi, V.; Russo, R.; Celentano, F.E. Animal Welfare Policies and Human Rights in the Context of Slaughter Procedures. Agriculture 2021, 11, 442. https:// doi.org/10.3390/agriculture11050442

Academic Editor: Eva Voslarova

Received: 12 April 2021

Accepted: 11 May 2021

Published: 13 May 2021

Publisher's Note: MDPI stays neutral with regard to jurisdictional claims in published maps and institutional affiliations.

Copyright: (c) 2021 by the authors. Licensee MDPI, Basel, Switzerland. This article is an open access article distributed under the terms and conditions of the Creative Commons Attribution (CC BY) license (https:// creativecommons.org/licenses/by/ $4.0 /)$.

\begin{abstract}
Human rights, such as to non-discrimination and freedom of religion, are internationally recognized. In the meantime, the so-called global animal law is becoming more and more important. In this context, religious slaughter is increasingly becoming a matter for debate as a number of special procedures, which avoid stunning methods, may lead to greater suffering for animals. Such procedures are common to Judaism and Islam and involve $25 \%$ of the global population, almost 2 billion people. Considering that about $94 \%$ of European public opinion in 2015 expressed concern over animal welfare, it is time to evaluate the legal perspective of these special treatments. Indeed, although they seem to violate animal welfare policies, at the same time states have a duty to uphold religious freedom (and its forms of expression) under International and European law. The aim of this study is to evaluate, through a multidisciplinary approach, the complex balance between human rights in general and animal welfare policies, which are gaining importance especially in the European Continent's legal framework.
\end{abstract}

Keywords: religious freedom; animal welfare; slaughter procedures; Council of Europe; European Union

\section{Introduction}

The international community, composed of states, has recognized during the last decades many rights related to human beings [1]. Among all there is the right to religious freedom, which includes the rights to express it, and, more generally, to non-discrimination. These rights influence food policies, just as every field of human life, and states have a duty to guarantee them via adequate food regulations.

In last years also animals are becoming object of interest from the legal perspective considering their nature, certified by science at different levels, of sentient beings [2]. This new approach, named the Global Animal Law, is the result of a complex balance between ethics, moral and human rights. Leaving apart aspects related to ethics and moral, which would push states to recognize some rights to animals, the object of the paper is the relation between animal welfare policies and slaughter in the context of religious freedom.

Animal slaughter is the process by which farmed animals are turned into meat [3]. This process is becoming increasingly crucial considering that it involves the production of food for humans and potentially causing great suffering to animals [4]. This context is already highly varied because of the different methods of slaughter used and the variety of environmental conditions, the human demand for more meat and the growing public 
interest in safeguarding animals $[5,6]$. As a result, specific methods of slaughter, particularly religious ones, have been the object of interest by legislative and judicial powers around the world [7]. In Section 2, we investigate religious slaughter, which are an exception to standard procedures of meat production. Given that the suffering in the animal's final moment is caused by humans themselves, by focusing on applying so-called "humane treatment" to animals during slaughter, the objective of this paper is to explore whether ritual slaughter and animal welfare can be reconciled, considering the human right to religious freedom under International and European law.

The essence of this exemption, freedom of faith, is an internationally recognized human right, which also includes, as explained in Section 3, how it is expressed (within the limits of the law). The reason why a discussion needs to take place about the consequences of religious methods of slaughter is related to the greater knowledge of their animal welfare implications. As happens in every other branch of the law, even in the nascent branch of animal rights, the question is: "How to find the right balance between the different rights and, consequently, express their relationship with economic and legal interests?".

\section{Religious Slaughter, What Does it Mean Concretely?}

Religious slaughter is carried out according to precise rules (blessings or invocations) prescribed by the religious rite. It is peculiar to some cultures such as Judaism and Islam and consists in killing a slaughter animal by severing its jugular vein, carotid artery, trachea and esophagus [8]. This operation is performed using a very sharp blade, generally without any preslaughter stunning, in compliance with current legislation [9].

The Arabic word Halal indicates what is allowed in accordance with Sharia law. Indeed, in order to be acceptable for Muslim consumption, this type of slaughter must meet conditions specified in the Qur'an and Hadith [10]. First of all, animals must have a preslaughter rest, and be well-fed and well looked after at the time of slaughter [11]. Preslaughter stunning can be performed but, in that case, it must necessarily be reversible, not resulting in the death of the animal, which must be alive at the point of slaughter. Indeed, if not slaughtered, stunned animals must be able to make a full recovery [10]. Regarding the slaughterer, he must be mentally stable and have reached the age of discretion. It is preferable that he be Muslim although the Qur'an allows Muslims to consume meat slaughtered by Christians and Jews [12]. The person performing animal slaughtering must pronounce the name of Allah for each animal, which should preferably face Qibla [12].

The word Shechitàh is used to describe Jewish slaughtering, whose rules include precise precepts to define kosher animals and select those suitable for religious slaughter, even during the breeding phase [13]. The cutting procedure must be performed by a specially trained religious slaughter man (known as the shochet) using a special knife called chalef [14]. The knife should be sharp and twice the length of the animal's neck, with no nicks or serrations, so that the incision is as painless as possible. In addition, the knife must be inspected carefully by running the blade along the fingernail before and after the Shechitàh [15]. The incision causes a rapid drop in brain blood pressure, rapid exsanguination of the animal and loss of consciousness within seconds, making the animal insensitive to pain $[15,16]$. Bleeding is followed by a post-procedure inspection, in which the animal is checked for lesions, especially in the lungs and liver. Based on the number and type of these pulmonary and hepatic injuries, the carcasses will then be classified as chalak (also known as glatt), kosher or terif [17]. After organ inspection, certain fatty parts and such organs as the kidneys, the intestines and the sciatic nerve are removed through a process called nikkur. Given that the blood is not considered edible, all large arteries and veins, and any bruised meat or coagulated blood, are removed. This removal is performed by specially trained practitioners called "porgers" [15]. On the other hand, this tedious and time-consuming practice of removing the forbidden sections from the hindquarters continues to be practiced in only a few places in Israel. Instead, the entire hindquarters, which contain most of the forbidden fats (e.g., omental fat, perirenal fat, and mesenteric fat) and the sciatic nerve, is sold on the general non-kosher market. The practice of selling 
the hind section has become so prevalent over the last century that there are very few trained porgers in the world and their number is steadily decreasing [18]. At the end of this selection, the koshering process takes place, through which the meat is purified from all its remaining blood [13].

In both Halal and Shechitàh slaughter, appropriate animal restraint is critical in maximizing animal welfare, while also improving the quality of the meat product, avoiding any blemishes or damage to the carcass, and safeguarding operator safety $[19,20]$. If animals panic due to inadequate restraint, the accuracy of the incision may be compromised, and multiple cuts may be required [21]. Some abattoirs turn the animals $45^{\circ}$ or $90^{\circ}$, others turn them on their back $\left(180^{\circ}\right)$ and others restrain the animals in an upright position, using a modified Cincinnati ASPCA (American Society for the Prevention of Cruelty to Animals) pen. However, rotary pens are frequently used in religious slaughter [22] causing considerable physical and mental distress to animals. Indeed, according to Velarde et al. [22], the percentage of struggling animals was higher when turned on their backs compared with the upright position or when turned on their sides. For this reason, at the European level, the Federation of Veterinarians of Europe has proposed the banning of the Weinberg pen and the prohibition of inversion [23].

Neck cutting must be carried out with a single movement of a very sharp knife and, moreover, each animal should be slaughtered out of sight of other animals and shielded from the sight of blood [10]. The act of slaughter begins with an incision on the animal's neck just below the glottis by cutting the animal's trachea and esophagus. The head must not be severed from the neck during slaughter [24]. Indeed, the cut is intended to achieve rapid bleeding and therefore needs to reach the major vessels, without touching the spinal column [13]. Slaughter shall be carried out from the front (towards the chest) and not from behind (towards the back). Finally, the carcass may not be processed, e.g., skinning, or cutting off the hocks, until the animal is completely dead [24].

The two different types of slaughter listed above have many similarities in principles and practice and many differences [25]. Indeed, during Kosher slaughter, the animal must be alive and conscious; any form of stunning, which makes the animal insensitive to pain before slaughter, is not acceptable; a special knife (chalef) is required for each species of animal, but blessing is not mandatory for each animal; a single mistake during kosher slaughter makes the meat unsuitable for human consumption and, moreover, some other parts of the carcass may not be eaten by the faithful. On the other hand, under the Halal rite, the animal must necessarily be alive before slaughter, non-stunning is preferred but reversible forms of stunning are widely accepted and practiced; post-slaughter stunning is also tolerated in order to prevent uncontrolled movements after animal bleeding. There is no special ritual knife, and it can be used for different species, but blessings are required for each animal. Although it is preferable for the neck to be cut with a single movement, where multiple cuts are required, the carcass will not automatically be excluded from the Halal market. Finally, all parts of the carcass are considered edible for the faithful [14].

\section{Religious Slaughter in Europe: The Necessity to Balance Rights and Public Expectations}

Each country has its own legal framework with specific laws to regulate animal slaughter. In Europe, there are also regional rules defined by Council of Europe (CoE) and European Union (EU). These two different institutions represent the meeting point between different legislative experiences that have the state governance's democratic approach in common. Indeed, the relevance of their regulations depends on the large number of countries they include: the CoE includes 47 member states, and the EU is made up of 27 states, which are all members of the Council of Europe.

From the legal perspective, slaughtering involves the freedom of religion, a wellconsolidated right, against a more recent approach to animals, known as animal welfare. If analyzed superficially, it might seem useless to discuss the problem, considering that a fundamental human right such as freedom of faith might seem to be automatically prevalent over a non-right, such as animal welfare, that involves animals rather than 
humans. However, the evolution of society is historically a reason of development for legal systems. In fact, at international and especially at the European level, animal welfare is gaining increasing importance among public opinion. At the same time, the protection and welfare of non-humans have become a matter of social and political interest. Indeed, in a survey conducted by Eurobarometer in 2015, 94\% of European citizens stated that "it is important to protect the welfare of farmed animals". Additionally, more than half of respondents (57\%) considered it to be "very important" and $37 \%$ to be "somewhat important" to protect the welfare of farmed animals. Only a very small proportion (4\%) of respondents do not consider the welfare of farmed animals to be important [26]. Such "common sense" is the main reason why the debate over balance between religious freedom and animal welfare is taking center stage.

Principally (but not exclusively) religious slaughter concerns Jews and Muslims who make up about $25 \%$ of the world's population [27]. The fact that such a high population is affected by religious slaughter has led to a derogation to prestunning conditions. Firstly, because of the importance of faith-related rights and secondly because, from an economic point of view, meat considered suitable by these communities is an important commercial asset for the food industry. From this perspective, it is fundamental to underline that, commonly, freedom of faith is not considered only as the human right to believe in a god, whatever his/her name might be, but above all the right to express faith. On the other hand, it is impossible to imagine the possibility to extend "human rights" to animals, considering that in many European countries they are still considered just as res rather than as sentient beings.

Regarding European norms, it is useful to mention Article 9 of the European Convention on Human Rights, adopted on 4 November 1950 [28]. The first paragraph of this article states that "Everyone has the right to freedom of thought, conscience and religion; this right includes $(\ldots)$ to manifest his religion or belief $(\ldots)$ ". Additionally, in the second paragraph, it adds that "Freedom to manifest one's religion or beliefs shall be subject only to such limitations as are prescribed by law and are necessary in a democratic society in the interests of public safety, for the protection of public order, health or morals, or for the protection of the rights and freedoms of others". Similar provisions are stated in many other previous and subsequent international conventions and are part of many constitutional texts, especially in Western countries, i.e., those where the debate on animal welfare and freedom of faith is more developed.

By contrast, attention to animal welfare, particularly at the time of killing for food purposes, is more recent and hence is less specific and articulated than freedom of faith. In fact, the first international legal instrument about slaughtering of animals is the European Convention for the Protection of Animal for Slaughter, adopted in 1979 [29]. Recently, the EU adopted Council Regulation (EC) No 1099/2009 of 24 September 2009 [9] concerning the protection of animals at the time of killing.

These norms have been adopted by different states in different cultural and historical moments and have in common the provisions concerning slaughter of the animal that "shall be stunned by an appropriate method", as reported in Article 12 of the CoE Treaty. Conventional methods of slaughter in general —and religious ones in particular-have been criticized on several occasions for their prohibition of stunning, which is considered a cause of great pain for the animal. Although religious slaughter might seem to be forbidden by European regional norms, it is actually permitted due to a specific exception provided both by Article 17 of the Convention and Recital 18 of the Regulation. Both norms underline the human right to religious freedom as a fundamental justification for postponing animal welfare.

In this context it is clear that the implication of different methods of slaughtering becomes increasingly relevant considering that citizens are developing a common sensibility on the topic. That explains why national legislators and the food market have to adopt changes based on how non-humans are treated and considered. This becomes 
necessary to balance the fundamental right to religious freedom with the rising sensibility for animal welfare.

\section{Non-Discrimination and Religious Freedom: Fundamental Human Rights Recognized at the International Level}

Religious freedom is one of the characteristic freedoms of the rule of law; since the end of the eighteenth century, it found its affirmation in major constitutional documents. In the past, the protection of religious freedom, and the protection of human rights and all fundamental freedoms, was traditionally entrusted to the internal jurisdiction of individual states. Today the protection of these freedoms is also exercised at the international level [30].

After the Second World War, there was a progressive emergence of a universal juridical consciousness, which opposes a conception of law exclusively focused on the normative power of the state with another based-on respect for the founding principles of the international community, among which the essential imperative emerges to respect the dignity of the human being. Today there is a growing awareness that the protection of fundamental rights can be effectively and fully implemented only if it is carried out at the level of international law, where the community of states can carry out tasks of control and guarantee [31].

Religious freedom, while having different connotations in different states, finds a common form of recognition and protection in the international legal system. According to the general interpretation of the international norms, religious freedom is the freedom to change religion and the freedom not to profess any religion, to manifest it in teaching, practice, worship, and observance, while maintaining the same rights of citizens who have different faiths. Therefore, it also includes the right for religious groups to bear witness and spread their message in society, without thereby being the object of contempt or persecution. Guaranteeing the religious freedom of the individual means providing the latter with the legal tools to express their beliefs. Indeed, at the international and European level, several norms have been specifically adopted, at different times, to guarantee fundamental human rights such as the freedom of faith and to non-discrimination (Table 1).

Despite what may appear to be a solid system of international protection of rights, its defense and development still constitute a legal challenge. Believing often means obeying religious prescriptions that come into conflict with other fundamental rights envisaged by legal systems. This creates a short circuit in the protection system that not even international standards are able to prevent, also due to the high number of cases. As will be seen in more detail below, the case of religious freedom of food in relation to the protection of non-human animals is emblematic in this context [32].

The general rules for the protection of religious freedom alone are not enough to regulate the specific expressions of this freedom. In order to be able to better define the forms of protection for the various expressions of religious freedom and how they relate to other freedoms and rights, an institutional dialogue needs to be set up between states and religious beliefs. This also serves to define the public role of each religious denomination. First of all, the case of the certification processes for religious products: here the religious body is part of the production chain, playing a public role.

The state, therefore, must clarify who is the interlocutor within the religious organization that performs this service. In the absence of a dialogue between states and religious authorities, difficulties can inevitably arise and damage citizens in many ways. In addition to the declarations of principle, it is becoming increasingly necessary to combine concrete legal instruments that could help define the boundaries between fundamental rights, thereby preventing inequalities and discrimination. 
Table 1. Some of the most important legal instruments in the field of non-discrimination and religious freedom and expression.

\begin{tabular}{|c|c|c|c|}
\hline Legal Instrument & Date of Adoption & Number of States Involved & Legal Provision Referred to Non-Discrimination and Religious Freedom \\
\hline Charter of the United Nations [33] & 26 June 1945 & 193 States & $\begin{array}{l}\text { States expressed their willingness to achieve international cooperation in } \\
\text { the solution of } \\
\text { problems of an economic, social, cultural or } \\
\text { humanitarian nature, and to promote and } \\
\text { encourage respect for human rights and } \\
\text { fundamental freedoms for all, without distinction of race, sex, language, or } \\
\text { religion (art. } 1,13,55,76) \text {. }\end{array}$ \\
\hline $\begin{array}{c}\text { Universal Declaration of Human } \\
\text { Rights [34] }\end{array}$ & 10 December 1948 & United General Assembly_193 States & $\begin{array}{l}\text { Provides that the rights and freedoms set forth in the declaration must be } \\
\text { recognized to all without the distinction of race, color, sex, language, } \\
\text { religion, political opinion of national or social origin, of wealth, birth or } \\
\text { other condition (art. 2). } \\
\text { Recognizes freedom of thought, conscience, and religion (art. 18). }\end{array}$ \\
\hline $\begin{array}{c}\text { European Convention for the Protection } \\
\text { of Human Rights and Fundamental } \\
\text { Freedom }[28,35]\end{array}$ & 4 November 1950 & Council of Europe-47 States & $\begin{array}{l}\text { Provides freedom of thought, conscience and } \\
\text { religion (art. 9), of expression (art. 10). It also } \\
\text { provides for a specific prohibition of any discrimination (art. 14). }\end{array}$ \\
\hline $\begin{array}{l}\text { Declaration on the Elimination of All } \\
\text { Forms of Intolerance and of } \\
\text { Discrimination Based on Religion or } \\
\text { Belief }[36,37]\end{array}$ & 25 November 1981 & United General Assembly_193 States & $\begin{array}{l}\text { No one shall be subject to discrimination by any State, institution, group of } \\
\text { persons or person on the grounds of religion or belief (Art. 2.1). } \\
\text { All States shall take effective measures to prevent and eliminate } \\
\text { discrimination on the grounds of } \\
\text { religion or belief in the recognition, exercise and enjoyment of human rights } \\
\text { and fundamental freedoms in all fields of civil, economic, political, social } \\
\text { and cultural life (Art. 4.1). }\end{array}$ \\
\hline $\begin{array}{l}\text { Lisbon Treaty-Treaty of the European } \\
\text { Union [38-40] }\end{array}$ & 13 December 2007 & 27 States & The Union shall respect cultural, religious and linguistic diversity (Art. 22). \\
\hline
\end{tabular}




\section{Concrete Problems Related to Specific Slaughter Procedures. More Pain for Animals, Less Transparency for Consumers?}

Religious slaughter often lies at the heart of several considerations, especially regarding the potential for animal suffering [5] or the lack of transparency in meat labeling $[11,41,42]$. Regarding the first point, some concerns have been raised about animal welfare referring to jugulation without prestunning, pain and distress caused by the restraining method, the cutting procedure, and the time after cutting, showing that slaughter without stunning causes pain [43]. Some authors suggest that, during religious slaughter, the blood supply to the brain is stopped quickly, causing an almost instantaneous loss of consciousness, with the death of the animal by bleeding [11,16]. On the other hand, other authors report that bleeding and loss of consciousness may take up to $1 \mathrm{~min}$ or more, thus compromising animal welfare $[44,45]$.

Stress indicators (cortisol, dopamine, norepinephrine and epinephrine) have been assessed in a study conducted on animals slaughtered by religious Jewish rite [46]. These values were then compared with those obtained from conventional slaughtering of beef cattle, which includes stunning. The stress indicators considered were measured during three different phases of the animal productive life: on the farm, after transport and during bleeding. The patterns of the tested parameters were similar and, interestingly, revealed extremely significant changes in two of the three steps considered (farm and bleeding). Indeed, animals slaughtered by the Jewish religious rite showed lower stress levels on the farm and after transportation to the slaughterhouse. This could be explained by the fact that the animals selected on the farm by the Rabbis for the religious rite are usually the most docile and gentle. On the other hand, the greatest variation between the two methods of slaughtering was observed immediately after the bleeding phase, appearing much higher in the animals slaughtered under the religious rite than in the animals slaughtered after stunning. It is important to underline that a high level of cortisol also negatively affects the organoleptic characteristics of the carcass. Indeed, the increased cortisol levels lead to a considerable decrease in marbling fat, a decrease that has an adverse effect on meat flavor and tenderness. This occurs because high levels of cortisol, even in the late slaughtering phases, play a central role in the process of proteins and fat degradation [47].

Regarding the second point, the lack of transparency in labelling is certainly a limitation of Jewish slaughter. Respecting the Jewish religion, according to which the hindquarters of a slaughtered animal are forbidden for human consumption unless purged of blood, sciatic nerve and fats [11], a twofold problem emerges: an economic one linked to the production costs that the slaughterhouse has to undergo due to the production delays caused by handling this type of slaughter; and an ethical one, since the carcasses regarded as Taref (i.e., unsuitable for consumption by the Jewish community, exclusively for religious reasons) are sold as meat from animals slaughtered in the conventional way. In this regard, it is essential to demonstrate that all meat placed on the market, obtained from animals slaughtered whether by a religious rite or by the conventional method, is subjected to the same health visits conducted by the veterinary inspector. These considerations suggest that there is a legislative gap regarding the production of kosher meat. Indeed, it appears evident that the consumption of Taref meat, without any indication concerning the type of slaughter, fails to protect any non-Jewish consumers who do not know how the animals were slaughtered. Therefore, it would be necessary to increase and improve the information on labels in order to resolve an ethical problem and provide the consumer with complete and clear information on the food chain [41].

\section{Is Animal Welfare Only a Method or a Right?}

The problems related to religious slaughter are also relevant because they impose a debate on the force and perspective of an animal's right to life and to humane treatment. Even though the former is an "impossible right" in light of the economic damage it would cause in the food industry [48]. 
It represents an approach to animals, especially to livestock, a way of treating them as more than just things, rather, and especially, as sentient beings. In this sense, Article 13 of the Treaty on the functioning of the European Union, adopted in 2007 [38], states that "In formulating and implementing the Union's agriculture, fisheries, transport, internal market, research and technological development and space policies, the Union and the Member States shall, since animals are sentient beings, pay full regard to the welfare requirements of animals, while respecting the legislative or administrative provisions and customs of the Member States relating in particular to religious rites, cultural traditions and regional heritage". On the one hand, it obliges the Union, and its member states, to treat animals in a certain way and, on the other, it gives them the right to derogate from such obligations for reasons of religion, culture and traditions.

This is the essence of the answer to the question concerning the nature of animal welfare. It is a general method that is becoming internationally recognized also due to public opinion, but it goes no further. Indeed, the European countries in their primary law, the above-mentioned treaty, declare that the (potential) animal right to consideration and strong protection stops in the face of human cultural and religious rights [49].

From this perspective, the role of veterinarians and the social responsibility of farmers become essential tools for achieving the ambitious aim of guaranteeing animal welfare in the food industry.

\section{Conclusions}

This interdisciplinary analysis highlights the importance of a technical approach to the issue of animal welfare as a method of food production and the related problems arising in the event of religious slaughter. Considering the strength of fundamental human rights, such as to express one's own faith, provided by norms at all levels, it becomes clear that in order to guarantee animal welfare and the consumer's right to transparency, the only instrument that we have are inspections and, where necessary, sanctions. The importance of veterinarians, who have to guide the meat production process, especially in the case of religious food, is evident and mandatory.

Confirmation of this approach derives, above all, from the European Court of Justice that on 29 May 2018, in judgment C-426/16 [50], stated that religious slaughter can be considered legal but that it shall be carried out only in recognized slaughterhouses. Moreover, European judges explained that "the obligation to carry out ritual slaughter in an approved slaughterhouse simply aims, from a technical point of view, to organize and manage the freedom to carry out slaughter without prior stunning for religious purposes. Such a technical framework may not restrict the right to freedom of religion of practicing Muslims". This means that respecting religious freedom is fundamental, but that animal protection must be guaranteed, proportionally and in line with needs of religious nature.

Considering the potential limitations to rights in the field of animal protection, religious organizations are called upon to ensure maximum transparency in the certification of production processes regarding meat suitable for specific believers. From this perspective, it is important to define, in agreement between states and religious communities, which internal and external bodies are authorized to carry out food certification activities and how these shall be conducted. The stipulation of pacts or specific agreements can facilitate the states in this monitoring by precisely defining the players in the dialogue between state and religious organizations.

The regulation of relations between Spain and Islamic communities [51-54] is a good example of how to facilitate dialogue between a state and religious bodies, also in the specific field of religious product certifications. On the other hand, in country such as Italy, the difficulty in establishing an institutional dialogue with all Islamic communities does not facilitate the definition of specific expressions of religious freedom. In such cases, regulatory interventions should help to clarify these relationships [55].

It seems that, in this varied framework, the questions concerning the balance of rights, production methods and public expectations can best (and most neutrally) be guided by 
science. This method would permit to leaving apart feelings, such as compassion, and, definitely, start to treat all animals equally in line with human rights.

Author Contributions: Conceptualization, G.B. and F.E.C.; writing-original draft preparation, G.B., R.B., D.F., V.G. and F.E.C.; writing-review and editing, G.B., R.B., R.R. and F.E.C.; supervision, G.B.; funding acquisition, G.B. All authors have read and agreed to the published version of the manuscript.

Funding: This research received no external funding.

Informed Consent Statement: Not applicable.

Conflicts of Interest: The authors declare no conflict of interest.

\section{References}

1. Focarelli, C. Trattato di Diritto Internazionale; UTET: Milano, Italy, 2015; p. 974.

2. Sykes, K. The Appeal to Science and the Formation of Global Animal Law. Eur. J. Int. Law 2016, 2, 497-518. [CrossRef]

3. Edwards-Callaway, L.N.; Calvo-Lorenzo, M.S. Animal welfare in the U.S. slaughter industry-A focus on fed cattle. J. Anim. Sci. 2020, 98, 1-21. [CrossRef] [PubMed]

4. Sabow, A.B.; Sazili, A.Q.; Zulkifli, I.; Goh, Y.M.; Ab Kadir, M.Z.A.; Abdulla, N.R.; Nakyinsige, K.; Kaka, U.; Adeyemi, K.D. A comparison of bleeding efficiency, microbiological quality and lipid oxidation in goats subjected to conscious halal slaughter and slaughter following minimal anaesthesia. Meat Sci. 2015, 104, 78-84. [CrossRef] [PubMed]

5. Blokhuis, H.J.; Jones, R.B.; Geers, R.; Miele, M.; Veissier, I. Measuring and monitoring animal welfare: Transparency in the food product quality chain. Anim. Welf. Potters Bar Wheathampstead 2003, 12, 445-456.

6. Loyer, J.; Whittaker, A.L.; Buddle, E.A.; Ankeny, R.A. A Review of Legal Regulation of Religious Slaughter in Australia: Failure to Regulate or a Regulatory Fail? Animals 2020, 10, 1530. [CrossRef]

7. Fernandes, J.; Blache, D.; Maloney, S.K.; Martin, G.B.; Venus, B.; Walker, F.R.; Head, B.; Tilbrook, A. Addressing animal welfare through collaborative stakeholder networks. Agriculture 2019, 9, 132. [CrossRef]

8. Nakyinsige, K.; Man, Y.; Aghwan, Z.; Idrus, Z.; Goh, Y.; Bakar, F.A.; Al-Kahtani, H.; Sazili, A.Q. Stunning and animal welfare from Islamic and scientific perspectives. Meat Sci. 2013, 95, 352. [CrossRef]

9. European Commission (EC). Council regulation (EC) 1099/2009 of 24 September 2009 on the protection of animals at the time of killing. Off. J. Eur. Union. 2009, L303, 1-30. Available online: https://eur-lex.europa.eu/legal-content/EN/TXT/?uri=celex: 32009R1099 (accessed on 4 February 2019).

10. Fuseini, A.; Knowles, T.G.; Hadley, P.J.; Wotton, S.B. Halal stunning and slaughter: Criteria for the assessment of dead animals. Meat Sci. 2016, 119, 132-137. [CrossRef]

11. Rahman, S.A. Religion and animal welfare-An Islamic perspective. Animals 2017, 7, 11. [CrossRef]

12. Qur'an. The Holy Koran; The World's Classics Paperback Edition; Arberry, A.J., Translator; Oxford University Press: Oxford, UK, 1983.

13. Farouk, M.M.; Al-Mazeedi, H.M.; Sabow, A.B.; Bekhit, A.E.D.; Adeyemi, K.D.; Sazili, A.Q.; Ghani, A. Halal and kosher slaughter methods and meat quality: A review. Meat Sci. 2014, 98, 505-519. [CrossRef]

14. Regenstein, J.M.; Chaudry, M.M.; Regenstein, C.E. The kosher and halal food laws. Compr. Rev. Food Sci. Food Saf. 2003, 2, 111-127. [CrossRef]

15. Zivotofsky, A.Z. Government Regulations of Shechita (Jewish Religious Slaughter) in the Twenty-First Century: Are They Ethical? J. Agric. Environ. Ethics 2012, 25, 747-763. [CrossRef]

16. Rosen, S.D. Physiological insights into Shechitàh. Faculty of Medicine, Imperial College, London. Vet. Rec. 2004, 154, 759-765. [CrossRef]

17. Mast, M.; Mac Neil, J. Effect of kosher VS conventional processing on yield quality and acceptability of broiler chickens. J. Food Sci. 1983, 48, 1013-1015. [CrossRef]

18. Zivotofsky, A.Z. Legal-ease: What's the truth about ... Nikkur Achoraim? Jew. Act. 2006, 67, 58-62. Available online: http:/ /www.ou.org/pdf/ja/5767/fall67/58-63.pdf (accessed on 11 March 2021).

19. Lambooij, E.; van der Werf, J.T.N.; Reimert, H.G.M.; Hindle, V.A. Restraining and neck cutting or stunning and neck cutting of veal calves. Meat Sci. 2012, 91, 22-28. [CrossRef]

20. Abdullah, F.A.A.; Borilova, G.; Steinhauserova, I. Halal criteria versus conventional slaughter technology. Animals 2019, 9, 530. [CrossRef]

21. Holleben, K.V. Handling and Restraining Issues for the Most Important Species. EU-Commission DG Sanco. In Proceedings of the Training Workshop on Animal Welfare Concerning the Stunning and Killing of Animals at Slaughterhouses and in Disease Control Situation, Zagreb, Croatia, 15-19 October 2007; Available online: http:/ / www.sancotraining.izs.it/news_corso03/training\%20 aid/16\%20October\%202007/von\%20Holleben.pdf (accessed on 5 March 2021). 
22. Velarde, A.; Rodriguez, P.; Dalmau, A.; Fuentes, C.; Llonch, P.; von Holleben, K.V.; Anil, M.H.; Lambooij, J.B.; Pleiter, H.; Yesildere, T.; et al. Religious slaughter: Evaluation of current practices in selected countries. Meat Sci. 2014, 96, 278-287. [CrossRef]

23. FVE. Position Paper on Slaughter of Animals without Prior Stunning; FVE/02/104; Federation of Veterinarians of Europe: Brussels, Belgium, 2002; Available online: https:/ / www.fve.org/cms/wp-content/uploads/fve_02_104_slaughter_prior_stunning.pdf (accessed on 9 March 2021).

24. Riaz, M.N.; Chaudry, M.M. Halal Food Production; CRC Press: Boca Raton, FL, USA, 2004.

25. Gregory, N.G. Animal Welfare and Meat Production, 2nd ed.; CABI Publishing: Wallingford, UK, 2007; pp. $213-226$.

26. Special Eurobarometer 442: Attitudes of Europeans towards Animal Welfare. Available online: https://ec.europa.eu/ commfrontoffice/publicopinion/index.cfm/ResultDoc/downlod/DocumentKy/71348ù (accessed on 10 October 2020).

27. Oggi tre Abitanti Della Terra su 10 Sono Cristiani. La Geografia Religiosa nel 2050. Available online: https://www.infodata.ilsole2 4ore.com/2019/01/08/oggi-tre-abitanti-della-terra-su-10-sono-cristiani-nel-2050-la-geografia-religiosa-sara-diversa/ (accessed on 10 October 2020).

28. European Convention on Human Rights. Available online: https://www.echr.coe.int/documents/convention_eng.pdf (accessed on 4 November 2020).

29. Convention for the Protection of Animal for Slaughter. Available online: https://rm.coe.int/1680077d98 (accessed on 10 October 2020).

30. Lugli, M.; Pasquali Cerioli, J.; Pistolesi, I. Elementi di Diritto Ecclesiastico Europeo; Giappichelli: Torino, Italy, 2008; pp. 9-10.

31. Zagrebelsky, V.; Chenal, R.; Tomasi, L. Manuale dei Diritti Fondamentali in Europa; Il Mulino: Bologna, Italy, 2019.

32. Ventrella, C. Il rispetto delle regole del cibo in una società multiculturale. Euro-Balkan Law and Economics Review. 2020. Available online: https: / / ojs.cimedoc.uniba.it/index.php/law/article/view/1155 (accessed on 10 October 2020).

33. The Charter of the United Nations. Available online: http://www.un.org/en/charter-united-nations/ (accessed on 12 October 2020).

34. The Universal Declaration of Human Rights. Available online: http://www.un.org/en/universal-declaration-human-rights (accessed on 5 October 2020).

35. Panella, L.; Zanghì, C. La Protezione Internazionale dei Diritti dell'uomo, 4th ed.; Giappichelli: Torino, Italy, 2019.

36. Declaration on the Elimination of All Forms of Intolerance and of Discrimination Based on Religion or Belief. Available online: https:/ / www.ohchr.org/EN/ProfessionalInterest/Pages/ReligionOrBelief.aspx\#: \{\}:text=Article\%204-,1.,political\% 2C\%20social\%20and\%20cultural\%20life (accessed on 5 September 2020).

37. Sullivan, D.J. Advancing the Freedom of Religion or Belief through the UN Declaration on the Elimination of Religious Intolerance and Discrimination. Am. J. Int. Law 1988, 82, 487-520. [CrossRef]

38. EUR-Lex. Treaty of Lisbon Amending the Treaty on European Union and the Treaty Establishing the European Community. Off. J. Eur. Union. 2007, C306, 1-271. Available online: https:/ / eur-lex.europa.eu/legal-content/EN/TXT/?uri=celex\%3A12007L\% 2FTXT (accessed on 16 March 2021).

39. Vitali, E.; Chizzoniti, A.G. Manuale Breve Diritto Ecclesiastico; Giuffrè: Milano, Italy, 2020; p. 29.

40. Fuccillo, A. Diritto Religioni Culture. Il Fattore Religioso Nell'esperienza Giuridica; Giappichelli: Torino, Italy, 2019 ; p. 57.

41. D'Amico, P.; Vitelli, N.; Cenci Goga, B.T.; Nucera, D.; Pedonese, F.; Guidi, A.; Armani, A. Meat from cattle slaughtered without stunning sold in the conventional market without appropriate labelling: A case study in Italy. Meat Sci. 2017, 34, 1-6. [CrossRef]

42. Bozzo, G.; Di Pinto, A.; Bonerba, E.; Ceci, E.; Mottola, A.; Roma, R.; Capozza, P.; Samoilis, G.; Tantillo, G.; Celano, G.V. Kosher slaughter paradigms: Evaluation of slaughterhouse inspection procedures. Meat Sci. 2017, 128, 30-33. [CrossRef]

43. Gregory, N.G.; Schuster, P.; Mirabito, L.; Kolesar, R.; McManus, T. Arrested blood flow during false aneurysm formation in the carotid arteries of cattle slaughtered with \& without stunning. Meat Sci. 2012, 90, 368-372.

44. Hayes, N.S.; Schwartz, C.A.; Phelps, K.J.; Borowicz, K.R.; Maddock-Carlin, K.R.; Maddock, R.J. The relationship between pre-harvest stress and the carcass characteristics of beef heifers that qualified for kosher designation. Meat Sci. 2015, 100, 134-138. [CrossRef]

45. Johnson, C.B.; Mellor, D.J.; Hemsworth, P.H.; Fisher, A.D. A scientific comment on the welfare of domesticated ruminants slaughtered without stunning. N. Z. Vet. J. 2015, 63, 58-65. [CrossRef]

46. Bozzo, G.; Barrasso, R.; Marchetti, P.; Roma, R.; Samoilis, G.; Tantillo, G.; Ceci, E. Analysis of stress indicators for evaluation of animal welfare and meat quality in traditional and Jewish slaughtering. Animals 2018, 8, 43. [CrossRef] [PubMed]

47. Gregory, N.G. Animal Welfare and Meat Science; CABI Publishing: Wallingford, UK, 1998; Chapter 4; pp. 64-92.

48. Fox, M.A. Animal liberation: A critique. Ethics 1978, 88, 106-118. [CrossRef]

49. Barzanti, F. La tutela del benessere degli animali nel Trattato di Lisbona. Riv. Dirit. Dell Un. Eur. $2013,1,49$.

50. Liga van Moskeeënen Islamitische Organisaties Provincie Antwerpen. Available online: http://curia.europa.eu/juris/liste.jsf? num $=C-426 / 16 \& l a n g u a g e=I T$ (accessed on 18 September 2020).

51. Rodriguez Garcia, J.A. Derecho Eclesiástico del Estado; Tecnos: Madrid, Spain, 2015.

52. Rodriguez Garcia, J.A. Laicità, interculturalità e "meticciato costituzionale democratico" in Spagna. Stato Chiese Plur. Confess. 2009. Available online: https://www.statoechiese.it/images/uploads/articoli_pdf/rodriguez_laicit.m.pdf?pdf=laicita-interculturalitae-meticciato-costituzionale-democratico-in-spagna (accessed on 15 March 2021). 
53. Llamazares Fernández, D. Derecho de la Libertad de Conciencia, Vol I., Libertad de Conciencia y Laicidad, 3rd ed.; Civitas: Madrid, Spain, 2007; pp. 1-417.

54. Castro Jover, M.A. Inmigración, pluralismo religioso-cultural y educación. In Laicidad y Libertades: Escritos Jurídicos; $\mathrm{n}^{\circ} 2$; Asociación Derecho, Laicidad y Libertades: Madrid, Spain, 2002; pp. 89-119.

55. Macrì, G. Immigrazione esperienze islamiche in Italia: La Consulta per l'Islam italiano. In Immigrazione e Soluzioni Legislative in Italia e Spagna. Istanze Autonomistiche, Società Multiculturali, Diritti Civile e di Cittadinanza; Tozzi, V., Parisi, M., Eds.; Arti grafiche la Regione: Campobasso, Italy, 2007; pp. 236-237. 